\title{
Auge y caída de José Ballivián en Bolivia (1841-1847). Construcción y derribo de la batalla de Ingavi como base legitimadora*
}

\author{
Rise and fall of José Ballivián in Bolivia (1841-1847). \\ Construction and demolition of the battle \\ of Ingavi as a base of legitimation
}

\author{
Pol Colàs \\ ORCID iD: https://orcid.org/0000-0003-2012-189X \\ Universitat de Barcelona, España
}

El objetivo de este artículo es mostrar la construcción discursiva alrededor de la victoria en la batalla de Ingavi (1841), ensalzando su importancia como segunda independencia de Bolivia ante el invasor peruano y «monstruo político» Agustín Gamarra, y José Ballivián, héroe unificador de las facciones irreconciliables del país, para legitimar su administración. A su vez, se pretende analizar el discurso contrario, formado por los opositores a la presidencia de Ballivián en el momento de su caída para deslegitimar su causa y justificar nuevos liderazgos en el país.

Palabras clave: Bolivia; Ballivián; Legitimidad; Inestabilidad Política; Siglo XIX.

The aim of this paper is show the discursive construction around the victory in the battle of Ingavi (1841), extolling its importance as Bolivia's second independence against the Peruvian invader and "political monster» Agustín Gamarra, and José Ballivián, unifier and hero of all the present factions of the country, to legitimize his administration. In turn, we intend to analyze the opposite discourse, formed by the opponents to the presidency of Ballivián at the time of his fall to delegitimize his cause and justify new leaderships in the country.

KeYwords: Bolivia; Ballivián; Legitimacy; Political Instability; $19^{\text {th }}$ Century.

Copyright: (C) 2021 CSIC. Este es un artículo de acceso abierto distribuido bajo los términos de la licencia de uso y distribución Creative Commons Reconocimiento 4.0 Internacional (CC BY 4.0).

* Esta investigación se ha desarrollado en el marco del proyecto I+D HAR2016-77609-P, financiado por la Agencia Estatal de Investigación (Ministerio de Ciencia, Innovación y Universidades) y el Fondo Europeo de Desarrollo Regional. Agradezco los comentarios de los evaluadores que han contribuido a mejorar ostensiblemente el artículo presente. 
Partidismo, tiranía, marcialidad, corrupción, personalismo, sed de venganza o clientelismo fueron etiquetas reiteradas durante el siglo XIX para calificar sendas administraciones de los llamados «caudillos» latinoamericanos. El término «caudillo» ha encerrado en su sino la mayoría de los calificativos maliciosos que pudieran asignarse al mundo político de la época. Ello llevó a utilizarlo como arma para deslegitimar la autoridad de la época anterior a la constitución del Estado-Nación y justificar la nueva ordenación estatal; ${ }^{1}$ es por eso por lo que, siguiendo con las consideraciones de estudios históricos recientes, evito ese término como definitorio en el presente texto. ${ }^{2}$

Aun soslayando el uso del concepto, conocer su existencia como dispositivo legitimador es conveniente, ya que en este artículo trato de explorar las estrategias de legitimación y deslegitimación que rodearon el mandato de José Ballivián en Bolivia (1841-1847). El análisis se sitúa en los márgenes de su administración, es decir, entre la batalla de Ingavi (1841) como primera referencia, dentro de la pugna entre partidarios de Andrés de Santa Cruz y José Miguel de Velasco, entre los que se erigió como tercera vía Ballivián; y el último mandato de Velasco (1848). Dentro del marco temporal que otorgan esas dos referencias, el objetivo es reconstruir los discursos velados desde el poder que justificaron tanto la institución de Ballivián como presidente, como su defenestración. Con «legitimidad»se referirá al poder aceptado en unas normas activas con las que los afectados por ellas pueden estar de acuerdo y demostrarlo con su participación; ${ }^{3}$ es decir, que quien ostenta el gobierno (o que la existencia del propio gobierno) puede hacerlo (o existir) por los méritos a los que clame adherirse sin un cuestionamiento social que pueda llevar a su caída inminente. En síntesis, el interés político de la sociedad, la confianza en la acción ejecutiva, legislativa o judicial, y una percepción del poder como aceptable y cuantificable a partir del estudio de la opinión pública ${ }^{4}$ y construible influyendo o monopolizándola (el fenómeno de la construcción de la legitimidad es llamado en este artículo «legitimación»).

Ballivián ha sido definido como «déspota por naturaleza, iracundo i ambicioso»,${ }^{5}$ militarista, abusivo y de carácter voluble, ${ }^{6}$ caudillo arribista,

Irurozqui, 2010, 257.

2 Irurozqui, 2016, 109.

3 Habermas, 1996, 107

4 En este artículo se toma una concepción de la legitimación «desde abajo», desde el prisma social y su comportamiento colectivo en la opinión pública (Weatherford, 1992, 150-152).

5 Sotomayor Valdés, 1874, 79.

6 Cortés, 1861, 189. 
«sin escrúpulos y torpemente ambicioso», ${ }^{7}$ «violento y autoritario». ${ }^{8}$ Descripción que casa con la del usual «caudillo» decimonónico latinoamericano trazable en la historiografía tradicional con anterioridad a la afirmación del Estado nacional boliviano. ${ }^{9}$ Lo que permite considerar que el discurso (des)legitimador destinado a apoyar una candidatura y desbaratar otra, alrededor del señalamiento de adscripción a los valores del «caudillismo» historiográfico, empezó inmediatamente después de haber caído la autoridad colonial.

A partir de esa afirmación, puedo articular la hipótesis que guía este artículo. José Ballivián utilizó la batalla de Ingavi y su victoria sobre el general peruano Agustín Gamarra para legitimar su presidencia como una tercera vía política entre Andrés de Santa Cruz y José Miguel de Velasco. Ingavi se convirtió en el fundamento discursivo de su poder, convirtiendo a Gamarra, el agresor, en un monstruo ${ }^{10}$ a batir para la consecución de una segunda independencia. Ballivián se erigió como líder representando la antítesis de Gamarra y propiciando su muerte. El relato de la batalla como momento fundacional empezó a circular en la opinión pública de la época y se convirtió en un mito nacional boliviano por la acción de la historiografía tradicional. No obstante, a la caída de Ballivián el discurso legitimador imperante tuvo que ser destruido y substituido por otro en la misma esfera pública, donde el propio Ballivián se convirtió en el nuevo monstruo a batir, el tirano a eliminar para dar un porvenir de éxitos a Bolivia. En el contacto entre discursos, en las estrategias de las fuerzas en pugna, ${ }^{11}$ se basará la argumentación.

La necesidad de abordar la política con nuevas preguntas, respondiendo a cuestiones donde la historia económica y social clásica no puede llegar por sus propios condicionantes, ${ }^{12}$ lleva a tratar conceptos como «legitimidad», «tercera vía», «monstruo político». Evito afirmar la existencia de una

7 Arguedas, 1967 [1922], 110.

8 Camacho, 1896, 135-136.

9 Que, según Démelas (1980, 191), para Bolivia llegó finalizada la Guerra del Pacífico contra Chile, en la década de 1880 .

10 En este artículo se hará referencia al simbólico «monstruo político» como el «caudillo» o tirano al que podrían adscribírsele todos los adjetivos negativos posibles que pudiera tener un gobernante, como se hizo un avance con la historiografía tradicional en el párrafo anterior. Corrupto, personalista, partidista, oportunista, asesino, adúltero, etc., eran algunos de los utilizados para convertir a ciertos individuos políticos, como Agustín Gamarra o José Ballivián, en monstruos. En otras palabras, un antihéroe del tipo lukacsiano, construido, como su contraparte heroica, como una sombre del hombre «vivo de la realidad histórica» (Lukács, 2010, 43).

11 Rosanvallon, 2003, 30-33.

12 Malamud, 2007, 19-21. 
inestabilidad decimonónica latinoamericana cultural, estructural o faccional ${ }^{13}$ para conocer el discurso en el que se basaba el cambio político en una época de intento de construcción de un régimen liberal y un proyecto nacional viable. ${ }^{14}$ Las ideas subyacentes que sostenían - y sostienen - lo político como nivel más abarcador de organización social ${ }^{15}$ son expuestas a partir del análisis histórico abarcando el alegato desde un sentido que desborda sus fronteras. ${ }^{16}$ Se desgranan así las intenciones últimas de los folletos, pláticas y escritos expuestas bajo el trasfondo de un liberalismo latinoamericano en construcción.

El edificio discursivo construido sobre Ingavi será interpretado a través de ejemplos provenientes del poder ejecutivo y de la figura de Ballivián en concreto en forma de folleto, de la Iglesia con un discurso, de la opinión pública con tratados y de la literatura con poesía de la época. En el caso de la destrucción de ese fundamento discursivo, se utilizan las proclamas de Eusebio Guilarte y de Velasco, así como el folleto titulado «Testamento de José Ballivián». Ambas cuestiones forman la estructura del artículo, dividido en dos capítulos discutidos en las reflexiones finales.

\section{1: la batalla de Ingavi como inicio}

En este apartado, son expuestos los hechos históricos que llevaron a la llegada de José Ballivián a la presidencia de Bolivia y, en paralelo, los que propiciaron la batalla de Ingavi. Asimismo, muestro el relato construido sobre la batalla como punto de inflexión para la República de Bolivia y su formación como base histórico-discursiva de la presidencia del personaje en cuestión. Contextualizando el suceso histórico, dilucido la constelación historiográfica formada a su alrededor desde el siglo XIX hasta tiempos recientes, y demuestro a través de fuentes tales como la Iglesia, la opinión pública, la literatura o los propios órganos del Estado, como el suceso fue magnificado para su glorificación.

El año 1841 fue uno de los más convulsos, en el ámbito político, vividos en Bolivia con anterioridad a la Guerra del Pacífico. Dos años antes había caído la Confederación Perú-Boliviana, creada por el mariscal Andrés

13 Safford, 1992, 83-92.

14 Morelli, 2004, 762.

15 Chartier, 1992, 3-15.

16 Derrida, 1998, 201. 
de Santa Cruz con la conquista, unión con Bolivia, y partición en dos Estados (Norte y Sur), del Perú. ${ }^{17}$ Sin embargo, tanto Chile como Argentina se mostraron totalmente contrarios a ese cambio, que podía perturbar el equilibrio geopolítico en la región, declarándole la guerra y apoyando a la oposición peruana, comandada por el general Agustín Gamarra. El ejército peruano-chileno logró vencer a Santa Cruz en Yungay, paralelamente al alzamiento del general José Miguel de Velasco en el sur de Bolivia, secundado por José Ballivián desde La Paz. Velasco, presidente desde 1839 y líder de la proclamada Restauración contra la Confederación Perú-Boliviana de Santa Cruz, no logró estabilizar el país e hizo frente a cinco golpes de Estado entre febrero y julio. ${ }^{18}$ La inestabilidad constante de su mandato se sumó a una pretendida reconcentración de poder en el legislativo, lo que le impidió tomar decisiones rápidas y/o drásticas contra los dos partidos o facciones de la oposición: el crucista y el ballivianista, de cariz presidencialista, que llegaron al año citado en plena expansión. ${ }^{19}$

Como señala Irurozqui, Velasco inició un proceso para subordinar el ejército bajo la política y aplacarlo como vector de la opinión pública armada, a favor de una ciudadanía cívica que, aunque representada en las Cámaras, como titular de la soberanía pudiera reapropiársela con las armas ante la tiranía o la amenaza de un mandato anticonstitucional; esto es, hacer del ejército un ente ajeno a las decisiones de la política, tomadas desde el poder legislativo delegado por la ciudadanía o por la acción directa de esta. ${ }^{20}$ Ese proceso siguió vigente en las siguientes administraciones. ${ }^{21}$ Aun así, el temor a la institución militar pensada por esta como soberana, con capacidad decisoria, se vio confirmado cuando el 5. ${ }^{\circ}$ Batallón tomó a Velasco como preso el 10 de junio de 1841 en Cochabamba y proclamó presidente a Santa Cruz, en nombre de la Regeneración crucista. ${ }^{22}$

Santa Cruz tardó demasiado en volver de su exilio en Guayaquil. La presidencia provisional fue repartida entre Sebastián Ágreda y Mariano Enrique Calvo, antiguos cuadros de la Confederación. Fueron sometidos a una

17 Colàs, 2019a.

18 Aranzaes, 1918, 27-37.

19 De hecho, Irurozqui $(2018,43)$ afirma que el golpe de Velasco y Ballivián contra Santa Cruz en 1839 era parte de la lucha entre el legislativo y el ejecutivo, en la que se impuso, en ese caso, el primero; en 1841 volvió el ejecutivo a tomar preeminencia, primero con la Regeneración, luego con Ballivián, teórico restaurador, pero, en tal caso, más cercano al crucismo.

20 Irurozqui, 2015, 72-75.

21 Irurozqui, 2016, 118-122.

22 Aranzaes, 1918, 30-31. 
gran presión dado que, ante la vuelta al poder de los crucistas, el presidente peruano, Agustín Gamarra, pasó a la acción para evitar una nueva política expansionista boliviana y se prestó a atacar al país vecino. ${ }^{23}$ Además, el peruano ayudó activamente a Ballivián, exiliado en Tacna, a volver a Bolivia para tomar el mando presidencial, ${ }^{24}$ en medio de motines militares, inestabilidad generalizada y alzamientos cívicos. ${ }^{25}$

El paceño Ballivián se configuró como imagen de una tercera vía política. Militar de primer nivel y mano derecha de Santa Cruz en tiempos de la Confederación ${ }^{26}$ formó parte fundamental en la génesis de la Restauración de Velasco en $1839 .{ }^{27}$ Cuando el legislativo lo descartó como vicepresidente, dio un golpe militar justificándolo como un acto de honor patriótico, contra el insultante elogio hecho por Velasco a Chile por su victoria en Yungay contra la Confederación. ${ }^{28}$ Ese alzamiento, aunque fallido y con el exilio peruano como consecuencia, le dio a Ballivián un aura de camino

23 Paredes, 1909, 4.

24 Sobre si Gamarra prestó o no ayuda a Ballivián para tomar el poder en Bolivia, hay varias teorías en la historiografía tradicional. Por un lado, René Moreno $(1970,24)$ consideró a Ballivián un «conspirador sin escrúpulo ni valla», y Arguedas (1967 [1922], 109-110) argumentó que el militar paceño «no tuvo reparos en entrar de acuerdo con Gamarra para conseguir que este invadiera el territorio de su país acaso sin sospechar de pronto que la intención de Gamarra no se limitaba solamente a la fácil empresa de hacer fracasar los planes de un grupo político». Por el otro, Paredes $(1909,2)$ apuntó que «Gamarra contuvo la explosión de sus resentimientos contra el general Ballivián y lo dejó conspirar; le convenía que se anarquisara [sic] Bolivia y se desangrase con sus luchas intestinas, para poderla uncir con facilidad al yugo que le preparaba», por lo que Ballivián no tuvo un papel consciente en la invasión peruana, o Santiváñez (1897) y Carrasco (1960), que negaron la relación. En este estudio se considera que, fuera solo con su inacción, Gamarra ya estaba así ayudando a Ballivián a conformar su propia facción política como alternativa de poder en Bolivia.

25 Para el tiempo que duró la Regeneración, entre julio y septiembre-octubre, Aranzaes (1918, II-III) considera la existencia de ocho revoluciones a favor de José Ballivián repartidas por todo el país y dos, en Sucre, por José Miguel de Velasco.

26 Colàs, 2019a.

27 «[...] ningún interés propio movió mis pasos, sino aquel que creí útil a mi patria en esas circunstancias: sometiéndome a la autoridad del Jeneral Velasco quien reportó las ventajas y la gloria. Entonces yo acredité con hechos, que no quería ascensos y que solamente la patria era el ídolo de mi corazón» (Ballivián, 1840a).

28 «...] me es dolorosamente repugnante, por más que la política lo aconseje: felicitar los bolivianos por la espléndida victoria de Yungay a los vencedores sobre el Ejército Boliviano, es cosa que primero me arrancarán la lengua, y me cortarán la mano que proferirla, o firmarla. ¿No es sangre Boliviana la que allí se ha derramado? ¿No son las armas Bolivianas las que se han humillado? El parte de Vulnes [sic] ¿no repite cien veces, que es el Ejército Boliviano, la cobardía Boliviana, y la tenacidad de los Bolivianos contra quienes han combatido? ¿La Historia no dirá que el Ejército Boliviano fue vencido en Yungay, y un renglón más abajo aparecerá el Cóndor de Chuquisaca diciendo: ¡Loor eterno a los vencedores de Yungay! y el Ministro Boliviano representante de su Patria, no se presentará humillado con todo esto? Que dirán las esposas, los padres y los hermanos que han perdido allí a sus espozos [sic], a sus hijos y hermanos?» (Ballivián, 1840b). 
alternativo para la presidencia de Bolivia entre Santa Cruz, con el que había colaborado y contra el que se había alzado, y Velasco, con quien se había comportado de igual manera. En consecuencia, Santa Cruz le propuso en repetidas ocasiones la unión de sus causas contra Velasco, ante lo que Ballivián se negó tácitamente, convencido de sus capacidades para llegar a la cúspide ejecutiva. ${ }^{29}$

La imagen de persona aún no corrompida, sin un bagaje específico que pudiera actuar como lastre en el mando, que sí tenían Santa Cruz y Velasco, le permitió aparecer como el único prohombre capaz de unir al país para frenar el ataque de Agustín Gamarra. Velasco, derrocado por los crucistas, era percibido como demasiado débil para acabar con el peligro peruano, ${ }^{30}$ mientras que Santa Cruz no era una opción viable, ya que la idea de su presencia era precisamente el casus belli para la inminente invasión. De forma paradójica, pronto los diputados que habían llamado a Ballivián «César de podre i barro ${ }^{31}$ y declarado traidor fuera de la ley en el golpe contra Velasco, lo reclamaron para asumir la magistratura. A esa decisión se doblegaron tanto crucistas como velasquistas, por la facilidad que suponía no tener que unirse a la facción totalmente contraria, sino a una intermedia: ${ }^{32}$ «los restauradores veían en Ballivián al representante de su causa, los rejeneradores [sic] al jeneral [sic] de la Confederación, i todos al guerrero que iba a salvar la patria», diría Cortés. ${ }^{33}$ Las llamadas a la unidad no cesaron después del 27 de septiembre de 1841, asumida la presidencia

29 Carta de Andrés de Santa Cruz a José Ballivián, Quito, 25 de febrero de 1840, Archivo Virtual Histórico del Mariscal Andrés de Santa Cruz, La Paz (AVMSC), Cartas del Mariscal, 18381843, pp. 238-239; respuesta en carta de José Ballivián a Andrés de Santa Cruz, Tacna, 12 de julio de 1840, AVMSC, Cartas al Mariscal, 1840, pp. 2-3. Santa Cruz se sentiría ignorado por Ballivián en su intento de reconciliación, diciendo haber contribuido «a la elevación de U. con mis débiles esfuerzos y ayudarle desde cualquier distancia al restablecimiento de la confianza pública y del crédito de Bolivia perdidos desde el funesto día en que se proclamó la Restauración; mas U. se ha negado sin causa ni pretexto alguno» a ayudarlo, en Carta de Andrés de Santa Cruz a José Ballivián, Guayaquil, 24 de septiembre de 1842, Colección privada de doña Florencia Ballivián, La Paz.

30 Camacho, 1896, 128-129. Sotomayor Valdés, 1874, 73.

31 «El presidente del congreso D. D. Mariano Serrano, orador bombástico, que trabajaba cuidadosamente sus discursos en el silencio del gabinete, llamó a Ballivián en una alocución, César de podre i barro: vana exaltación, desmentida después por la sumisión más absoluta» (Cortés, 1861, 159-160). En 1841, a la entrada de Ballivián en Bolivia, el mismo Serrano le anunció que «todas las autoridades, todos los ciudadanos, todos los partidos que se han reunido, con excepción de muy pocos individuos, en torno de V.E. que sin duda alguna, es el único capaz de reorganizar el país, según el voto nacional y de ahuyentar la anarquía, en que la república se halla envuelta» (Arguedas, 1967 [1922], 109-110).

32 Arguedas, 1967 [1922], 110-111. Carrasco, 1960, 72. Irurozqui, 2016, 122.

33 Cortés, 1861, 173-174. 
de Ballivián: ${ }^{34}$ «BOLIVIANOS TODOS: Uníos en torno al Gobierno; ayudadle a defender la patria y vuestros caros intereses, y estad seguros de que el Jeneral [sic] Gamarra encontrará su tumba en el suelo boliviano, que aborrece de corazón; que llegó el momento en que el Perú se liberte para siempre de este hombre aciago que detesta, y de que la gloria corone vuestros esfuerzos». ${ }^{35}$

La situación de urgencia, con Gamarra en la frontera a punto para invadir Bolivia y — según se afirmaba — anexionar La Paz al Perú, ${ }^{36}$ permitió a Ballivián transformar su carácter alternativo, de tercera vía, en imagen de centralidad política, con los partidos antagónicos cerrados entorno a su figura. El hecho de tener apoyo crucista dio a Gamarra un argumento para continuar su cruzada contra Bolivia, considerando el nuevo presidente títere del mariscal Santa Cruz. ${ }^{37}$ Aunque Ballivián trató de evitar la contienda, ${ }^{38}$ gracias a la unión de sus tropas con las del - hasta ese momento rebelado-general Velasco, se alzó con la victoria en Ingavi el 18 de noviembre de 1841 .

La batalla de Ingavi es considerada como un punto de inflexión en la historia de Bolivia. En la historiografía tradicional, el suceso fue invariablemente ensalzado, fueran escritores contrarios o afines a Ballivián. Los autores decimonónicos consideraron que la independencia había dejado de ser un problema; dada la muerte de Gamarra y el gran papel de los bolivianos ${ }^{39}$ para la conservación de una paz duradera con sus vecinos, se propició por

34 Decreto. El Sr. General José Ballivián acepta el mando supremo de la República. Declara insubsistentes las Constituciones políticas de 834 y 839, 27 de septiembre de 1841. Colección Oficial de Leyes..., 1858, vol. 7, 186-187.

35 Ballivián, 1841, 18.

36 La anexión de La Paz al Perú fue un tema recurrente, tanto como la del departamento de Moquegua a Bolivia, y centró varios debates en la opinión pública. Véase, Refutación de la Época al Republicano de Arequipa..., 1845.

37 «Solamente el Jeneral Gamarra es capaz de un atentado tan escandaloso: la autorización que le otorgó el Consejo de Estado de su patria para hacer la guerra a los partidarios del Jeneral Santa Cruz, ha cesado ya desde que terminó su objeto; él mismo lo tiene declarado así de antemano. No queda, pues, ninguna duda de que este hombre funesto jamás tiene pudor de ser malvado», quedando sin legitimar la continuidad su ataque (Ballivián, 1841, 18).

38 «1 anunciaros este acontecimiento feliz [la presidencia de Ballivián], me es muy grato participaros el sentido recto de esta Nación, el orden y el reposo que reinan en todo su territorio, y su firme adhesión al sistema que de consuno con los Estados de la América meridional proclamó en el pasado año de 1839, y de ofreceros en mi administración la más sólida garantía de paz y de amistad con el pueblo peruano, cuyos intereses estrechamente unidos con los de Bolivia, serán consolidados por la uniformidad de sus votos y por la identidad de los principios que animan a sus gobiernos», dijo Ballivián por correspondencia (Carta de José Ballivián a Agustín Gamarra, La Paz, 1 de octubre de 1841, en Ballivián, 1841, 24-25).

39 Cortés, 1861, 177-178. Camacho, 1896, 131-132. 
ende la perpetuación de la República. ${ }^{40}$ La consideración de Ingavi como momento fundacional fue unánime, también en autores tan críticos con los gobernantes de la época llamada «caudillista» como Moreno o Arguedas, ${ }^{41}$ y convirtió, en cierto modo, a Ballivián en un pater patriae comparable a Bolívar y Sucre. ${ }^{42}$

Si bien la unicidad del momento, como segunda independencia o consolidación de ella, ha sido reconocida ampliamente hasta estudios recientes, ${ }^{43}$ las consecuencias políticas inmediatas de la victoria han exigido una mayor discusión. En el debate entre detractores y afines se aprecia un ruido de fondo, un supuesto inicial en ocasiones explícito, en otras oculto, y es que Ingavi fue la base histórico-discursiva que legitimó el poder ejercido por José Ballivián en Bolivia desde 1841 hasta 1847. Más allá de su prestigio político, de sus aptitudes para el ejecutivo, los fundamentos del poder de Ballivián fueron bélicos, derivados de la consecución marcial de la segunda independencia.

Habiendo firmado la paz de Puno con el Perú un año después de la batalla, en 1843 se convocó la Convención Nacional para redactar una nueva Constitución para Bolivia, alrededor de la cual se pueden relatar las consideraciones de los investigadores anteriores. Dando un mayor poder al ejecutivo y coartando el legislativo, en comparación con la de $1839,{ }^{44}$ esa Constitución «no podía leerse, según se decía en aquel tiempo, sino al brillo de la espada de Ingavi». ${ }^{45}$ Arguedas insistió en ese aspecto:

Esa nueva Constitución, dictada con propósito de servir a un hombre, reconocía la irresponsabilidad del presidente, le alargaba a ocho años la duración de su mandato, le daba facultad de disolver el parlamento y nombrar el personal de la Corte Suprema, es decir, que hacía del mandatario un ser munido de mil prerrogativas, dueño de obrar sin control y a su capricho, disponiendo a su antojo de los puestos públicos y del poder judicial y libre del control celoso y vigilante de las cámaras que sólo debían

40 Se dice que Ballivián actuó «no teniendo nunca miras de volver la ofensiva contra el Perú» (Cortés, 1869, 183), aún la existencia de una invasión sobre Arica, Tacna y Puno hasta el 1842.

41 Arguedas, 1967 [1922], 113. Moreno, 1970, 27.

42 Lo que explica la presencia de su retrato completo, junto a los de Bolívar y Sucre, en el salón de la independencia de la Casa de la Libertad, en Sucre. Carrasco (1960, 83-84) afianzó la consideración de Ballivián como padre de la patria ya en el siglo XX, mientras que Paredes $(1909,48)$ lo comparó con Sucre.

43 Véase, por ejemplo, el estudio de Macías Kraljevic (1991), que toma como hilo conductor la supuesta destreza militar de Ballivián.

44 Irurozqui, 2018, 43.

45 Se trata de una frase citada en varias fuentes, probablemente por el uso de los autores posteriores de los textos de los anteriores como base para ciertos períodos históricos. Cortés, 1861, 179-180. Camacho, 1896, 133-134. 
reunirse cada dos años, según la nueva Carta, calificada al punto y con propiedad por los pueblos de ordenanza militar. ${ }^{46}$

A su vez, Gabriel René Moreno afirmó que «el conspirador sin escrúpulo ni valla [Ballivián] alcanzó por fin su anhelada presidencia, no por manos del invasor ni acaso tras un desastre de Bolivia, como lo andaba negociando, sino por la fuerza moral irresistible de una espléndida victoria en Ingavi». ${ }^{47}$ Ballivián consideró que el logro de sus objetivos, que pasaban por la aplicación de un amplio programa de reformas, exigía obtener el apoyo de todos los partidos. Como afirma Irurozqui, se fundamentó en Ingavi, el momento de mayor unión de las facciones existentes luchando en el mismo bando contra un enemigo común, como ejemplo y base de unión patriótica que estabilizara al país alrededor de su proyecto, de su programa. ${ }^{48}$ La fuerza de la victoria en la unión, que había demostrado la batalla, le permitió articular su mandato alrededor de esa idea, otorgando competencias al ejecutivo para evitar injerencias partidistas y centrarse en la educación, el ámbito militar, la economía o la expansión oriental. ${ }^{49}$ Aún antes de la contienda, con la imagen de tercera vía política y como mal menor aceptado circunstancialmente por crucistas y velasquistas por su centralidad, Ingavi dio una mayor dimensión al joven general y le permitió justificar su giro hacia la primacía del ejecutivo que, huelga decir, ostentaba su persona.

Como he señalado, considero la batalla de Ingavi como base histórico-discursiva de la administración de Ballivián. Ello implicó necesariamente la construcción de un discurso legitimador y triunfante en la época a partir del suceso. A modo de aparato propagandístico, se inició una campaña para la deificación festiva ${ }^{50}$ de Ingavi en la opinión pública desde el Estado, instituciones afines, como la Iglesia, el ensayo y la literatura, calando de forma profunda para la legitimación del proyecto ballivianista y en el relato nacional boliviano posterior propagado en parte, y como hemos visto, a partir de la historiografía tradicional.

Desde el Estado, se promocionó la publicación para la consulta de toda la ciudadanía de la documentación administrativa, privada y pública, relacionada con los sucesos que llevaron a Ingavi. El ejemplo más claro fue

46 Arguedas, 1967 [1922], 115.

47 Moreno, 1970, 27.

48 Irurozqui, 2015, 87-90.

49 Para la expansión del Estado boliviano hacia los Orientes, iniciada por la administración de Ballivián, véase Groff Greever, 1987; García Jordán, 2001; Guiteras Mombiola, 2012.

50 Bridikhina, 2010, 248. 
el documento titulado «Campaña de cuarenta días, hecha por el Ejército boliviano al mando de S.E. el Jeneral D. José Ballivián, contra el Ejército invasor del Perú a las órdenes del Jeneralísimo de sus armas D. Agustín Gamarra». ${ }^{51}$ Colección de documentos que tenía como objetivo democratizar los sucesos alrededor del episodio bélico y difundirlos para fomentar la unidad discursiva y de facciones.

El relato que se intentó construir y permear a la sociedad consistió, primero, en la llegada de un monstruo, Agustín Gamarra, que por su codicia pretendió «la violación de los derechos más sagrados» de los bolivianos con la destrucción de su nacionalidad, de su propia existencia. ${ }^{52}$ Los actos propiciaron la transformación del presidente peruano de agente que ayuda a Bolivia en la caída del crucismo y la llegada de Ballivián, con la declaración de guerra, a traidor por su insistencia a seguir con ella, ya que cuando

por el voto unísono de sus ciudadanos fue llamado S.E. el actual Presidente provisorio [José Ballivián] a rejir [sic] los destinos de su Patria del mismo Perú donde se había asilado, debió creer que se habían removido todos los motivos que podían haber alarmado al pueblo peruano por el restablecimiento de una administración, que tan justamente le era repugnante [la de Santa Cruz], [pero] el Gobierno de Bolivia ve, no sin dolor ni asombro, que las fuerzas peruanas tratan de internarse a esta República, como si aun fuese enemiga del Perú, como si estuviese bajo la férula del tirano que detestan ambas, y como si no presidiese sus destinos el mismo Jeneral [sic] que ha cruzado los planes populicidas de los caudillos del 10 de Junio: el que ha recibido tantas pruebas de consideración de aquel gobierno, y el que es la más completa garantía que puede ofrecérsele de los sentimientos de amistad y estimación perfecta hacia la Nación Peruana y su Gobierno. ${ }^{53}$

Aunque se añade la respuesta de Gamarra a las peticiones de paz bolivianas, resumida en la pregunta de «¿Cómo pues bastará el último cambio [la llegada de Ballivián] por si solo para ofrecer seguridades al Perú, cuando en todo se deja conocer su inestabilidad, y cuando amigos y ajentes [sic] de Santa-Cruz mueven y lo disponen todo?», ${ }^{54}$ Ballivián se esforzó en desmarcarse del crucismo y de los peruanos y en señalar a Gamarra como pérfido conquistador. En ese sentido, mandó dos proclamas, una dirigida a la ciudadanía y la otra al ejército. En la primera, dijo que «el enemigo constante

51 Se considera a Ballivián como el autor, por ser además el principal emisor de los documentos que recoge el título, pero puede descartarse categóricamente que él mismo hiciera la recopilación. Existen varios ejemplares; el consultado se encuentra en el archivo de la Casa de la Libertad, Sucre.

52 Ballivián, 1841, 5.

53 Ibidem, 7.

54 Ibidem, 11. 
e inplacable [sic] de Bolivia, el Jeneral [sic] Gamarra», sin hacer caso a las llamadas pacíficas del ejecutivo boliviano e «inconsecuente a los mismos principios que ha proclamado, y haciendo alarde de su mala fe y perfidia, se ha introducido a marchas redobladas a nuestro suelo». Consideró no haber pedido ayuda a Gamarra, siendo las intenciones del peruano simplemente malignas, ya que su «objeto es buscar pretestos [sic] para dividirnos y despedazarnos $\gg .{ }^{55}$ En la segunda, expuso que Gamarra atacaba porque suponía al país dividido, por lo que apeló a la unión militar para liberar a Bolivia de una invasión y al Perú de un tirano. ${ }^{56}$ La unidad, el bloque de los bolivianos frente a una amenaza exterior o para el progreso, era la salida necesaria para Ballivián de la crisis post-independencia; en ese momento, en contraposición y frente al monstruo peruano.

Entonces, la unión llevó a la derrota del monstruo. Se cumplió «el deber más sagrado que el cielo y el honor pueden imponer a sus valientes: salvar la Patria de la conquista, de la humillación y de la esclavitud» en «la batalla más célebre que pueden ofrecer a la posteridad los fastos de nuestra historia militar». ${ }^{57}$ Se decía, la independencia de Bolivia quedaba asegurada para siempre gracias a cincuenta minutos de combate y la muerte del malvado conquistador; pereció este ante una simple demostración de patriotismo boliviano. Para Ballivián, «la victoria de Ingavi, será el principio de una nueva era para Bolivia, si todos de acuerdo nos proponemos consolidar su existencia política, su seguridad y sus progresos». Es decir, el porvenir pasaba por el acuerdo, la unión alrededor de su figura como vencedor que demandaba «pedir una recompensa inestimable por la pequeña parte que he tenido en la jornada de Ingavi; tened confianza en mis intenciones; prestadme vuestra cooperación para que hagamos de consumo la felicidad de nuestra Patria, y podamos ofrecer a la historia el espectáculo de un gobierno $\mathrm{y}$ de un pueblo rivalizando en patriotismo». ${ }^{58}$

Esa felicidad, el éxito del nuevo gobierno restaurador capitaneado por Ballivián, debía ir ligada a la aceptación de él como líder y de un proyecto común que era el que él proponía; si doblegarse a Ballivián como general funcionó en Ingavi, hacerlo como presidente debería funcionar para dar un halagüeño futuro para la República de Bolivia. El «pueblo rivalizando en patriotismo», es decir, unido bajo unos preceptos compartidos a defender

55 Ibidem, 17-18.

56 Ibidem, 18-19.

57 Ibidem, 30-31.

58 Ibidem, 35-36. 
por todos, como lo fue la victoria a cualquier precio en la batalla anterior; un patriotismo como sinónimo de concordia. Ingavi, pues, como punto central en el esquema de la necesaria unidad en el proyecto restaurador de Ballivián para todo el país.

Desde la Iglesia, se tomó el propósito de convertir la batalla de Ingavi en una clara y directa intercesión divina. Dios tomó partido por Ballivián en la contienda, como toda Bolivia había hecho, y ello debía extenderse al apartado de lo político en lo sucesivo. Documento ejemplificador puede ser el Discurso pronunciado por el Dr. José María Yáñez de Montenegro, cura propio de la doctrina de Chulumani, y Vicario Jeneral del Ejército, en el solemne aniversario del Glorioso Triunfo de Ingavi, el 10 de Noviembre de 1842.59

Para el vicario general del ejército, el día de recuerdo de la batalla de Ingavi era una celebración extendida entre todos los bolivianos, en el que «aun el tierno infante, el helado anciano, y el secso [sic] al que la naturaleza y la educación alejan de los asuntos graves, participan del influjo de su hechizo». ${ }^{60}$ Primero, se «consagrará al Señor, manifestándole como nosotros el debido culto relijioso de gratitud» por la victoria, ya que «Ingavi hizo resplandecer la magnificencia de su nombre, la fortaleza de su brazo y la ternura de su corazón protejiendo [sic] la justicia de nuestra causa y proporcionándonos el descanso, la opulencia, la seguridad y la paz». Luego, a Ballivián, «el más ilustre, esforzado y magnánimo boliviano», que condujo a «un puñado de valientes» hacia la victoria. ${ }^{61}$

Pero si bien Dios y Ballivián fueron los principales artífices del triunfo, este no habría ocurrido sin la unión del país. «En Ingavi desaparecieron los partidos que fomentó la discordia, y nació en los bolivianos un solo sentimiento y un solo corazón», allí el pueblo boliviano «adquirió respetabilidad, nombradía, y un realce que jamás se empañará; el patriotismo puso el colmo a sus proezas, y esta grande empresa que atrajo la admiración, no solo del continente, si también del antiguo mundo, que nos contempla ya con asombro». ${ }^{62}$ La nobleza del hecho de olvidar lo que propiciaba la separación partidista y conjuntar destinos bajo un mismo estandarte, el que lideraba Ballivián bajo la égida de Dios. La victoria no era un fin, sino un

59 En este caso, se desconoce el autor, aunque como el documento anterior puede ser consultado en el archivo de la Casa de la Libertad, Sucre.

60 Discurso pronunciado por el Dr. José María Yáñez de Montenegro..., 1842, 1.

61 Ibidem, 2.

62 Idem. 
inicio, y como tal su grandeza podía ser desaprovechada. Para evitar tal cosa, la Iglesia exigía «no una administración estéril, sino que contemplándola con un espíritu verdaderamente nacional y relijioso [sic], continuéis a porfía ejercitando esas sólidas virtudes con que alcanzamos el triunfo, para asegurar y consolidar la paz». ${ }^{63} \mathrm{Si}$ no se continuaba con el comportamiento de unidad inquebrantable alrededor del gobierno y su proyecto, se corría el peligro de una infección generalizada en el cuerpo del Estado. «Es imposible padezca un miembro sin condolerse los demás; del mismo modo es indispensable sean sensibles entre sí, los miembros de una nación» ${ }^{64}$ lo que se evitaba luchando todos con ahínco con el mismo objetivo.

Desde la opinión pública, surgieron varios proyectos para el progreso económico de Bolivia durante la década de 1840. Dos de los que tuvieron más importancia y repercusión fueron los de Julián Prudencio, adalid del proteccionismo radical, y Félix Frías, defensor de la expansión del Estado hacia los Orientes. Aunque la distancia entre ambas tesis es meridiana, el argumento básico para proponerlas fue el mismo: con Ballivián era posible el desarrollo del país por haber conseguido la unión de los partidos a su alrededor.

En un primer escrito, Prudencio se confesó admirador del pensamiento económico del liberal francés Jean-Baptiste Say, esto es, del comercio libre como fuente de riqueza. No obstante, negó que para sostenerlo se debieran «dejar incultos y despoblados los campos, los hombres sin ocupación, sin actividad el comercio interior por falta de industrias nacionales como sucede con nosotros» ${ }^{65}$ En la Bolivia crucista se habrían aplicado conceptos económicos liberales sin tener en cuenta las condiciones propias del país, que requería de la protección comercial para florecer en una industria nacional, una agricultura fuerte y la erradicación de los principales problemas del país, la empleomanía, el hambre y las guerras intestinas por el poder ${ }^{66}$

Le siguió un segundo escrito en el que Prudencio fue más incisivo en el ámbito político. En él, señaló como problemas «1. ${ }^{\circ}$ de la falta de instrucción: $2 .^{\circ}$ de la de capitales: $3 .^{\circ}$ de la incertidumbre que se tiene del resultado de las especulaciones atendido el estado del comercio exterior». ${ }^{67}$ Consideró que

63 Ibidem, 3.

64 Idem.

65 Prudencio, 1842a, 6.

66 Ibidem, 17.

67 Prudencio, 1842b, 12. 
en Bolivia nada progresará si el Gobierno no mueve la industria, resorte único de la prosperidad de los pueblos. Un solo movimiento que se comunique de su parte, dará impulso a la masa inerte de pueblos, que sin instrucción, ni medios de mejorar, no saldrán jamás del letargo que los consume. Toda acción que emana del centro de la autoridad pública, que es el depósito de todas las facultades individuales, es como la del sol que colocado en el zenit de su carrera, da vitalidad a todos los seres que cubren la superficie de la tierra, sintiendo todos su influjo benéfico. La Administración pública como encargada de la felicidad común, es en efecto la única que puede restituir a la vida el cuerpo exánime de Bolivia. ${ }^{68}$

Aún y la evidente crisis económica y social, el Estado podía proponer soluciones efectivas. Eso era debido a que con la nueva administración, se presentaban en Bolivia «los sucesos políticos con aspecto favorable a su prosperidad», ya que «la paz exterior que acaba de ratificarse, y la interior que debemos a S.E. el Vencedor de Ingavi, nos ofrecen las más lisonjeras esperanzas». Mientras los planes de Ballivián no se turbasen «por alguna aspiración funesta», no se disputaría «con mano armada la posesión de un empleo, pues la administración pública nos abrirá las fuentes de la abundancia». ${ }^{69}$ Era el nuevo presidente, quien había conseguido ratificar una segunda independencia, quien había unido los varios partidos en un único proyecto, capaz de sanar a Bolivia de sus males estructurales utilizando el aparato estatal. Un Estado fuerte, capaz de hacer olvidar aspiraciones partidistas, era la clave del éxito para el país.

En el caso del argentino Félix Frías, personaje influyente en el entorno del presidente Ballivián, ${ }^{70}$ la salida a la crisis económica implicaba otro tipo de acciones, sin descartar tampoco el proteccionismo económico. ${ }^{71}$ Sin embargo, su propuesta esencial implicaba, con los misioneros católicos como punta de lanza ${ }^{72}$ y con impulso a la industria, introducir al Estado en el vasto territorio ocupado por «tribus salvajes» $;{ }^{73}$ en los poco poblados y no controlados Orientes, repletos de supuestas riquezas por explotar. En Bolivia, la solución al laberinto económico recaía en olvidar el puerto de Cobija como punto de contacto con el comercio internacional, totalmente insuficiente por sus malas infraestructuras y su lejanía de los centros productores, y el de Arica por pertenecer al Perú, y conectar con el mercado atlántico por vía

68 Ibidem, 13.

69 Ibidem, 1.

70 Carrasco, 1960, 114. Groff Greever, 1987, 202-203.

71 Frías, 1846, 2.

72 Frías, 1844, 6. Para el concepto de la religión como punta de lanza del Estado en los Orientes, véase García Jordán y Sala i Vila, 1998, 15.

73 Ibidem, 84-86. 
fluvial, a través del río Paraguay o del Madera. ${ }^{74}$ No era algo fácil de aplicar debido a que, desde las independencias,

La América Española ha sido teatro de las más estériles pasiones políticas, que alejándose de las necesidades reales de la sociedad, para ponerse esclusivamente [sic] al servicio de causas individuales i mezquinas, han deslustrado las glorias adquiridas a tanta costa en la lucha de la independencia, desacreditando al mismo tiempo el réjimen [sic] democrático que hemos adoptado, i que ha sido tan frecuentemente abatido por los escesos $[s i c]$ del despotismo o de una licenciosa anarquía. ${ }^{75}$

Las repúblicas americanas habían sido afectadas políticamente por las «influencias personales» y la «falta de preparación en estas sociedades para adaptar a sus costumbres una civilización avanzada». ${ }^{76}$ Para Frías, las diversas facciones nacidas del conflicto contra la Corona Española habían utilizado a la ignorante población para imponer por las armas su propio proyecto, llevando a una continua inestabilidad que impedía el progreso y la gobernabilidad. Ante ello, Bolivia tenía una oportunidad de futuro en Ballivián. «Desde los primeros días de su elevación al poder, le hemos visto apartar su corazón i su intelijencia [sic] de los pequeños i pobres intereses de partido para contraerse únicamente a los intereses graves i permanentes del país», ${ }^{77}$ encarnando el progreso y olvidando las diferencias políticas para liderar una unidad político-discursiva que impusiera un proyecto válido para Bolivia.

Ballivián, para Prudencio y Frías, era la clave del progreso para Bolivia. Sus escritos, con trascendencia en la opinión pública, moldearon el discurso repetido desde el Estado y la Iglesia para ver al vencedor de Ingavi como el padre de la patria que, con la paz exterior en una mano, por la gloria bélica, y la paz interior en la otra, por la unión de facciones políticas en su proyecto, podía alzar a Bolivia hacia la estabilidad y la riqueza.

Desde la literatura, finalmente, se mistificó el suceso de Ingavi, de forma parecida a la glorificación eclesiástica, alrededor de la unificadora figura de Ballivián. En ese sentido, dos textos son especialmente interesantes: La jornada de Viacha, relato poético anónimo publicado en 1841, y A la

74 Frías, 1846, 4-16. Una idea de la necesidad de olvidar el Pacífico para centrarse en el Atlántico compartida con Palacios $(1852,26)$, que consideraba que «nuestros hombres de estado en vez de pensar en Arica o Cobija, deben dirijir [sic] todas sus combinaciones y miras a la navegación del Madera. Conseguida esta, no necesita Bolivia de otra cosa para llegar a ser feliz, y asegurar una existencia, que aunque sea triste confesarlo, ha sido y será muy precaria».

75 Frías, 1846, 20.

76 Ibidem, 20-21.

77 Ibidem, 21. 
gloriosa memoria del inmortal D. José Ballivián, de 1853, del conocido poeta y político paceño Ricardo José Bustamante.

En el primer caso, un texto anónimo dedicado enteramente a la victoria de Ingavi, se considera a Bolivia como una «madre desdichada», víctima de sus propios hijos que, desgarrando su seno, le habían preparado «su inocente cuello» para las «cadenas de oprobio y de ignominia». ${ }^{78} \mathrm{La}$ esclavitud a la que Gamarra quería sumir Bolivia era, así, consecuencia de las luchas intestinas de los bolivianos, que el peruano habría tratado de aprovechar para alcanzar una ansiada unión republicana del Bajo y el Alto Perú. ${ }^{79} \mathrm{Ba}-$ llivián fue invocado por la propia Patria para dar muerte al invasor, y conseguido su propósito, el país debía premiarlo con su absoluta lealtad, como se ejemplifica en estos versos:

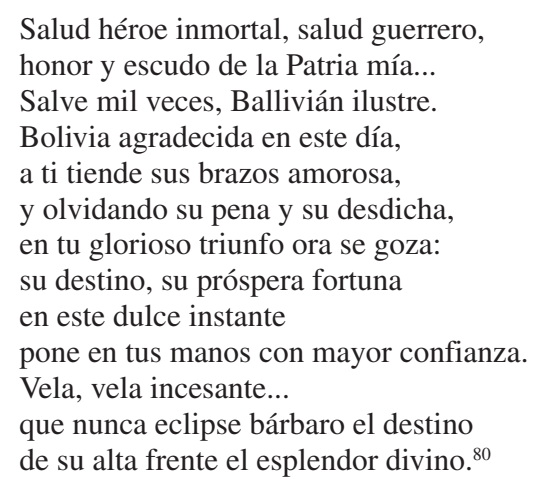

La confianza en Ballivián se traduce en la alianza discursiva, en la unificación de proyectos, en el final de las luchas intestinas que provocaron esa pena y desdicha. Y si eso fue posible, como he ido remarcando con las diferentes fuentes, fue por el «glorioso triunfo» de Ingavi. El destino «bárbaro» de la Patria, luchando contra sí, era neutralizado por los laureles de la aglutinadora batalla.

En el caso del célebre poeta Ricardo José Bustamante, la llamada a la unidad no fue tal, debido a que el texto, publicado en 1853, fue redactado con relación a la muerte de Ballivián, un año antes, y seis años después de

78 La jornada de Viacha, 1841, 6.

79 Gamarra basó, en parte, su mandato como presidente del Perú en la consecución del proyecto de unión perseguido también por Andrés de Santa Cruz. Sin embargo, en su caso, no sería confederal, sino unitario y centrado en Lima, lo que implicó la constante lucha antagónica entre ambos generales. Véase, Colàs, 2019a; 2019b, 18.

80 La jornada de Viacha, 1841, 17. 
dejar la presidencia. Aunque eso lo descarta como fuente para la construcción de un discurso legitimador alrededor de Ingavi, constituye un testimonio temprano de la mistificación de la batalla que se llevaría a cabo en la literatura posterior a la propia administración de Ballivián como uno de los grandes momentos de la historia de Bolivia.

$\mathrm{La}$ «lumbre» del choque bélico llevó a Bolivia y a sus soldados a «la esplendente cumbre» del triunfo, desde donde pudieron ver, «sobre el campo, a los que fueron osados en traer violenta guerra, besar el polvo de la hollada tierra» ${ }^{81}$ Entre todos los individuos que propiciaron la victoria, el nombre más glorioso era el de Ballivián, que pronunciándolo «las puertas rompe del eterno olvido». La victoria en Ingavi convirtió al general en inmortal, pero eso no impidió lo que Bustamante considera un crimen, y es que «yngrata [sic] lo olvidaste, y hoy lo lloras cuando él ya huella las eternas horas» ${ }^{82}$ la victoria, finalmente, no permitió perpetuar a Ballivián en el cargo, cayendo por la ingratitud y miras personales de sus sucesores.

Por tanto, a partir de ciertos ejemplos representativos concretos de fuentes relativas al propio general Ballivián, a la Iglesia, a voces reputadas de la opinión pública y a la literatura, puede reconstruirse la gradual edificación de un discurso glorificador alrededor de la victoria de Ingavi. Este debía suponer la base legitimadora a partir de la cual asumir la autoridad de Ballivián y la primacía de su proyecto nacional, a partir de mantener una completa unidad de facciones como la vivida en la batalla, después de la aceptación de los crucistas del nuevo presidente y la alianza circunstancial con Velasco contra Gamarra. Ingavi se convirtió en el fundamento del mandato de Ballivián - así como la derrota del monstruo devorador de patrias en el que se había convertido Gamarra- y a través de los historiadores clásicos de Bolivia, base de la misma existencia del país, convirtiéndose en uno de los momentos fundacionales para su historia patria.

\section{7: el Testamento Político de José Ballivián como final}

En el siguiente apartado, son explicados los sucesos históricos que llevaron a la caída de José Ballivián, junto con la creación de un discurso en contra de su autoridad, justo después de su caída, para justificar la de los nuevos líderes en boga, como Guilarte o Velasco. Ballivián fue convertido en un monstruo y tirano, como otrora Gamarra, cortando de raíz las

81 Bustamante, 1853, 5-6.

82 Ibidem, 6-8. 
posibilidades de su facción. Para verlo, analizo tres documentos paradigmáticos para la destrucción de su figura.

1847 fue un annus horribilis para la causa ballivianista. Después de años de estabilidad, el enquistamiento de la mala coyuntura económica, en parte por el peso desproporcionado del ejército en el erario, herencia de tiempos de la Confederación crucista, se hizo sentir como un terremoto político. Ballivián había gobernado sin notable oposición desde la batalla de Ingavi, pero el patrimonio discursivo de esta parecía acabado en el año citado. Aranzaes apuntó la existencia de once sublevaciones contra el presidente, fueran desde el acérrimo crucismo, de ambientes cercanos al presidente peruano Ramón Castilla, de José Miguel de Velasco o del joven oficial Manuel Isidoro Belzu, pretendiendo un cambio en el paradigma faccional del escenario político boliviano. ${ }^{83}$ Arguedas, más específico, señaló tanto a Castilla, con ánimo de venganza por la derrota de Ingavi, como a Belzu, «cuyas relaciones con el presidente se habían enfriado bastante desde una secreta intriga de alcoba en que ambos se vieron mezclados»,${ }^{84}$ como agentes de la caída de Ballivián, causada por la tendencia autoritaria del presidente y laudatoria de su gabinete. ${ }^{85}$ En la influencia peruana sobre Belzu y el final del mandato de Ballivián se coincide generalmente, ${ }^{86}$ dado el apoyo de Castilla al primero y la coincidencia de la guerra arancelaria del Perú contra Bolivia con la llegada de la inestabilidad en el país. ${ }^{87}$ De esta manera, sorprende que Ballivián no considerara a Belzu como un enemigo a batir, sino que el principal siguiera siendo Santa Cruz, ${ }^{88}$ exiliado en Europa.

83 Los dos últimos, Velasco y Belzu, eran en teoría aliados, algo que, finalmente, no se cumplió en la práctica, surgiendo rivalidad entre ambos. Ballivián tuvo que ver en ello, como se verá a continuación (Aranzaes, 1918, 59-77).

84 Arguedas, 1967 [1922], 127-128. Aventuras extramatrimoniales de Ballivián con Juana Manuela Gorriti, esposa de Belzu, son destacadas también por Carrasco $(1960,166)$ como motivo de tirantez política.

85 «La labor presidencial, desmesuradamente loada en tono ditirámbico por los ministros y demás altos colaboradores que haciendo abstracción de su propia labor personal lo referían todo al presidente; la actividad de Ballivián, realmente desconcertante» (Arguedas, 1967 [1922], 119-121).

86 Cortés, 1861, 184. Sotomayor Valdés, 1874, 82. Aranzaes, 1918, 60.

87 «Castilla, como todos los gobernantes peruanos, tenía una arma formidable para herir a Bolivia: suspender el tráfico por Arica, o imponer con mayores gabelas los artículos de exportación bolivianos. Hizo lo último, y Ballivián le respondió en igual forma imponiendo a los productos peruanos los mismos derechos que a los de ultramar» (Arguedas, 1967 [1922], 127).

88 «Han trabajado mucho este país, extraviando sus ideas sin perdonar medios. Sin desconocer los autores del trastorno que debían salir mal, se han lanzado, y esto entra en su plan, se han propuesto conflagrar al país para fines posteriores; parece que hay instrucciones de Santa Cruz porque sus principales agentes han obrado y han hecho obrar a Olañeta para echarle luego la culpa». Carta de José Ballivián a Domingo de Oro, Potosí, 25 de noviembre de 1847, Archivo Histórico del Museo Mitre, Buenos Aires (AHMM), C. 28 C. 65, f. 64. 
La coyuntura negativa para la administración, de revueltas y golpes de Estado, sufrió una interrupción el 7 de noviembre del mismo año, en la batalla de Vitichi. Ante la proliferación de conspiraciones en el sur del país contra el gobierno, Ballivián se desplazó encabezando su ejército y derrotó, cerca de Potosí, a Sebastián Ágreda, crucista aliado con Velasco. Vencido ese alzamiento, pareció verse capaz de retomar el control sobre Bolivia y, al resurgir Belzu en el norte, pretendió batirlo «como en Vitichi» había hecho con Ágreda. ${ }^{89}$ Vitichi pudo constituirse como un nuevo Ingavi, una refundación que acabara con las facciones internas y reunificara la política de la República. No obstante, pronto la realidad se impuso a la voluntad de poder. La revuelta militar de Belzu en el norte abría las puertas a una costosa guerra civil que, finalmente, Ballivián evitó dimitiendo del cargo que pasó al presidente del Consejo de Estado, Eusebio Guilarte, el 23 de diciembre de $1847 . .^{90}$

Confirmada la caída de Ballivián, la opinión pública se volcó en la deslegitimación de su figura para justificar la llegada de nuevos liderazgos. A continuación, ejemplifico el proceso a partir del análisis de tres documentos. Por una parte, la perorata de Guilarte, en una posición difícil por no tener una facción de apoyo clara y por esa razón con un tono conciliador; por otra, la de Velasco, a la ofensiva contra todo lo que pudiera representar Ballivián y, finalmente, el «Testamento de José Ballivián», ensayo irónico contra el exiliado paceño y favorable al partido velasquista.

En primer lugar, Guilarte trabó una justificación de la conducta que siguió en los sucesos inmediatamente posteriores a la dimisión de Ballivián, siendo elegido presidente de forma oficial siguiendo los preceptos de la constitución de 1843. En especial, se desmarcó del «absolutismo y ulteriores planes anárquicos» del general Ballivián para evitar que los hechos que lo podían vindicar ante la opinión pública quedasen «sepultados entre los escombros de la revolución». ${ }^{91}$ Dado que la prensa había condenado su vínculo de sucesión con el «tirano», consideró un deber dilucidar los

89 Camacho, 1896, 136-138. Aranzaes, 1918, 69.

$90 \ll[. .$.$] mi persona ha servido de pretexto y debo apartarla dejando el mando y para comprobar$ que en Vitichí no se ha combatido por sostener el poder sino la constitución y las leyes. Deseo que esta parte se esfuerce con ideas francas, abiertas y decisivas, porque en efecto, he empleado toda mi vida desde mi niñez en el servicio público y deseo descansar, necesito de ello; ya no puedo resistir más y mucho menos en el suplicio del poder que es insoportable. Estoy desesperado y sería capaz de desertarme; serviré de general, sostendré al gobierno, haré lo que Páez, pero no quiero mandar. Carta de José Ballivián a Domingo de Oro, Potosí, 25 de noviembre de 1847; carta de José Ballivián a Domingo de Oro, 5 de diciembre de 1847, AHMM, C. 28, C. 65-66, ff. 64-65.

91 Guilarte, 1848, 3. 
hechos desde su perspectiva para evitar repetir ser significado como «traidor», como ocurrió en la última derrota de Santa Cruz en Yungay. ${ }^{92}$

La revolución en el norte de Bolivia no se disolvió con la marcha de Ballivián, sino que la llegada constitucional de Guilarte pareció catalizarla. Él lo consideró injusto, dado que había conseguido el que, parecía, era el objetivo principal del alzamiento, la caída del «tirano», sin derramamiento de sangre más que el inevitable en Vitichi:

Si yo al aceptar la renuncia del General Ballivián he querido sostener la opresora y despótica administración de aquél; si en el acto no empezé [sic] a separar de los destinos esas piedras de escándalo con que por seis años se había lastimado la opinión pública; si no abrí las puertas de la Patria a todos los proscriptos por Ballivián, restituyéndolos a sus honores y empleos; si no he evitado la guerra civil y sus horribles consecuencias, alejando del mando y del país al funesto mandatario, sin reparar en el sacrificio de mi propia reputación y hasta de mi existencia, caigan sobre mi cabeza todos esos anatemas con que el grito de la libertad ensordece los aires [...]; puesto que he sido como es notorio la víctima que más cruelmente ha perseguido Ballivián, ¿porqué se me quiere envolver en las ruinas del que fue mi verdugo ${ }^{93}$

Guilarte, víctima del fratricidio entre los bolivianos, había tratado de conciliar ambos bandos exigiendo la dimisión de Ballivián, que debía suponer la vuelta a la estabilidad. El gobernante se resistió, dada la gloria conseguida en Vitichi y los laureles de Ingavi. ${ }^{94}$ "Ordenó la creación de nuevas fuerzas: pidió recursos de todo género y en fin él solo dictó todas las providencias consiguientes» para continuar con la guerra contra los alzados. ${ }^{95}$ Clamaba contar con la lealtad del ejército por haberlo colmado de

92 «Vuestra Merced debe saber que la revolución tenía que estallar en Puno y en Bolivia, cualquiera que fuese la suerte del Ejército, como que ha estallado en Oruro y Chuquisaca sin conocimiento de lo sucedido en Yungay. Aquel ha sido un efecto anticipado de las combinaciones fraguadas en Bolivia. Guilarte, Sierra y Sagárnaga han estado de acuerdo con Ballivián. No podía ser de otro modo». Carta de Andrés de Santa Cruz a Belford Hinton Wilson, a bordo del Samarang, 26 de febrero de 1839, AVMSC, Cartas del Mariscal, 1838-1843, pp. 204-205. La fama de Guilarte como traidor, fuera o no cierta, se trasladó desde el final de la época crucista al ocaso de Ballivián, cuando logró ser uno de los presidentes de más breve mandato en la historia boliviana. Camacho, 1896, $137-$ 138. Belzu, en un decreto el 28 de diciembre de 1847, declaró que «El usurpador José Ballivián y todos los que le sostengan, son declarados traidores insignes», entre los que se incluyó Guilarte. Archivo y Biblioteca Nacionales de Bolivia, Sucre (ABNB), MI, 77/37, 28 de diciembre de 1847, f. 2.

93 Guilarte, 1848, 5.

94 «U. nos ha obligado a dar este paso; no es U. querido como Presidente; los pueblos están cansados de U. pero como al guerrero Capitán de Ingavi le guardan a U. algunas simpatías: renuncie U. el mando en el Consejo; se tendrán con U. todas las consideraciones posibles, y hasta la de su permanencia en el país». Ibidem, 4.

95 Ibidem, 7-8. 
ascensos ${ }^{96}$ pero Guilarte consiguió la renuncia de Ballivián antes de una nueva batalla a cambio de que este conservara el mando del ejército hasta su salida al exilio. El nuevo presidente se consideró un hombre ajeno a la lucha partidista, lo que debía permitirle liderar un proceso de conciliación y consolidación de las instituciones, el orden legal y la paz interna. ${ }^{97}$ Era el intento de dar vigor a su incipiente presidencia a partir de la misma legitimidad apartidista que Ballivián había construido alrededor de Ingavi.

Para Guilarte, el plan de Ballivián no consistió en una simple dimisión y posterior exilio. El rendido general pretendió avivar la sedición e intrigas entre los diversos pretendientes a la presidencia para, supuestamente, crear un ambiente irrespirable que propiciara su pronta vuelta a la magistratura suprema. Cuando el nuevo gobierno provisional expidió un decreto para la vuelta de Velasco, Olañeta y Ágreda, el antiguo mandatario «siempre fecundo en traiciones, orden[ó] a Lafaye y a los López el que se defeccionaran y proclamaran a Belzu Presidente», y poco después «mand[ó] al comisario España para que le di[jera] a Belzu que trabaj[as]e para sí y no permit[iese] que Velasco» volviese a Bolivia. ${ }^{98}$ Ballivián, en su camino a Cobija, sublevó las tropas a favor de Belzu para convertir a Bolivia en ingobernable y en efecto se vivieron varias conspiraciones al paso del héroe de Ingavi hacia el exilio chileno..$^{99}$

En el texto, Guilarte mostró varios de los recursos que la oposición acérrima a Ballivián usaría para deslegitimar su poder. Como homus novus, habló desde una posición de honor esbozando al héroe de Ingavi como una antítesis de sus valores: absolutista, personalista, partidista, traicionero. Después de un mandato oscurecido por el autoritarismo y perpetuado por el triunfo contra Gamarra, Ballivián pretendió recomponer su autoridad a partir de una nueva victoria, esta vez contra sangre boliviana; la gloria personal fosilizaría su partido en el ejecutivo. Al no poder llevar a cabo su plan dada la evidencia de pérdida de control que Guilarte le mostró personalmente, Ballivián se fue no sin antes cometer la perfidia de levantar Bolivia a favor de uno de los pretendientes que más odio arrojaban contra él para alimentar la confusión e inestabilidad. Para el autor, el genio malvado de Ballivián era

96 Ibidem, 8.

97 Ibidem, 9-10.

98 Belzu, aunque alejado de Ballivián, aceptó el rol de choque contra Guilarte y lo trató, según este, con «odio personal». Ibidem, 10-12.

99 Se sucedieron cinco revueltas contra Guilarte y a favor de Belzu en la brevedad de su presidencia, que se extenderían a la llegada de Velasco a la cúspide del ejecutivo. Aranzaes, 1918, V. 
irrefutable en su traición para el bien propio con el mal de la patria. Hizo Bolivia ingobernable para convertirla en su jardín privado, como pretendió Gamarra en 1841, por lo que era fácil establecer un paralelismo que la oposición se ocuparía de llevar a colación. Ballivián era el nuevo monstruo que debía permitir legitimar los incipientes liderazgos del país.

En segundo lugar, Velasco representó al ala más lejana al ballivianismo en la oposición, y acabando con Guilarte, asumió la presidencia. ${ }^{100}$ Desde allí, relevó el discurso crítico pero conciliador de este último para pasar a una ofensiva directa a la figura de Ballivián, «en cuyo tiempo ha hollado los principios más venerables de la revolución de América, violando las condiciones más esenciales de toda sociedad humana, y cometiendo crímenes horribles para sostener su autoridad usurpada». ${ }^{101}$

Velasco, por haber sido anteriormente llamado en cuatro ocasiones a ocupar la presidencia, se consideró idóneo para amalgamar el clamor boliviano contra su tirano y presentarlo como su propio relato ante las naciones americanas, ${ }^{102}$ esto es, la unión de discursos — facciones, partidos — en su causa. Los pueblos de Bolivia se habían alzado «sin coacción de ninguna clase y sin más recurso que su desesperación», con el objetivo de desconocer «la autoridad de Ballivián, la denuncian usurpadora, la condenan tiránica, y me llaman de su espontánea voluntad a la primera majistratura [sic] del Estado». ${ }^{103} \mathrm{El}$ país entero, hasta sus propios aliados, se alzaron contra el presidente ya que,

con sus crímenes internacionales, su deslealtad y perfidias comprometía con nuestros vecinos de Sud y Norte la independencia nacional. Tanto había sufrido la nación condenada a un silencio sepulcral, tal era el odio público que enjendró [sic] la estúpida tiranía, y tanta y tan descarada la desmoralización social, que los ciudadanos menos interesados, y que miran con horror toda revolución por sus consecuencias siempre funestas, creyeron que no cabía otro remedio a nuestros males. ${ }^{104}$

100 Con pronunciamientos sucediéndose durante todo el 1847, el breve mandato de Guilarte solo retrasó su vuelta a la presidencia. ABNB, MI, 123/41, 10 de noviembre de 1847; ABNB, MI, 123/49, 17 de diciembre de 1847.

101 «El grito de Libertad que en Octubre último lanzó Bolivia [a favor de Velasco] en medio de su desesperación y dolor, ha sido interpretado de rebelión, y apellidado anticonstitucional por el opresor, cuyo gobierno no conoce más fundamento legal, ni sabe otro modo de mandar que el de la soberanía del sable, y el poder de la fuerza brutal con que sacrifica las víctimas que señala su capricho, y con que impone silencio a las leyes, y ahoga la espresión [sic] de la voluntad nacional». Velasco, 1848, 1.

102 Idem.

103 Ibidem, 2.

104 Ibidem, 3. 
El tirano había castigado, amenazado e insultado magistrados, hollado los derechos de los ciudadanos, vaciado el erario, injuriado a la Confederación Argentina y al Perú, y sometido Bolivia a las facultades extraordinarias del ejecutivo. Razones que invalidaban relacionar la rebelión de Velasco como «lucha de los partidos» o «aspiración al poder de frenéticos demagogos», siendo «la expresión franca de la voluntad nacional» contra el continuo atropello del presidente. ${ }^{105}$ «Un patriotismo a toda luz desinteresado, y el entusiasmo ardiente de los pueblos» guio la caída de Ballivián y el auge para el retorno de Velasco.

Para justificar su vuelta, deslegitimó la vía seguida por Ballivián desde 1839 hasta 1841 . Siendo Velasco presidente, «Ballivián, a quien había confiado la mejor y mayor parte del ejército, levantó el estandarte de la revelión [sic] militar, invistiéndose de su propio beneplácito, de la potestad suprema a presencia del Cuerpo Lejislativo [sic]». Fue derrotado y exiliado al Perú, $\mathrm{y}$ «no cesó desde el estranjero [sic] un solo momento en promover motines militares, soplar sediciones, y crear obstáculos insuperables a la organización social del país que Yo [Velasco] entonces presidía». ${ }^{106}$ Intentó de todas formas posibles llegar al poder, con el motín, el soborno, el asesinato, la seducción y la traición, hasta prometer a Agustín Gamarra la anexión del departamento de La Paz al Perú. ${ }^{107}$ El general va más allá, debido a que:

Cuando el fuego de la guerra civil devoraba la patria, y en circunstancias en que corría la sangre de sus compatriotas por la lucha de los partidos que Ballivián había azuzado e incendiado, aconseja al Jeneral [sic] Gamarra una invasión, ofrécele la incorporación del departamento de la Paz al Perú, jura protejer [sic] la empresa; y luego que bajo esa influencia y ese poder ocupa el mando, siempre perjuro y pérfido, vuelve las armas contra su aliado, proclama la independencia nacional que vendió, y con el patriotismo y el valor boliviano derrota al mismo ejército que condujo. ${ }^{108}$

La victoria de Ingavi perdía, para Velasco, todo significado, dado que fue propiciada por la oferta de Ballivián a Gamarra para desmembrar

105 Idem.

106 Ibidem, 4.

107 «Ballivián que cuando impera, oprime, esplota [sic] y humilla su patria, manda cantar hasta el fastidio la batalla de Ingavi, ordena inmortalizar su nombre como defensor de la independencia boliviana, y que en sus mensajes, proclamas, y actos públicos ostenta un amor estudiado a esa independencia; en la emigración y en el infortunio, intenta borrar el nombre de boliviano y aniquilar la nacionalidad de su patria. Para Ballivián mandatario sin principios, soldado sin conciencia política y hombre de la más honda inmoralidad, la independencia nacional, la patria, sus derechos y felicidad no han sido más que palabras con que ha jugado según sus intereses personales, sus miras inicuas y sus crímenes en las diferentes situaciones en que se ha visto colocado» (Ibidem, 4-5).

108 Ibidem, 5. 
su país a cambio de la presidencia. La perfidia del paceño fue justificada - $\mathrm{O}$ anulada, escondida - por la gloria de las armas y el discurso legitimador alrededor de la victoria, pero Velasco estaba dispuesto a deshilvanarlo para romper con el mito de la segunda independencia ganada por Ballivián, que fue quien puso en peligro a la patria. No solo eso, sino que, desde la óptica velasquista, «abusando de la victoria, insult[ó] los restos mortales del Jeneral Gamarra» y «engrill[ó] al Jeneral Castilla, que más tarde mand[ó] apalear amarrado, d[io] de sablazos al Coronel Coloma, estrope[ó] al de igual clase Cisneros, maltrat[ó] de hecho y de palabra la desgracia de los prisioneros», violando toda ley de la guerra, y por ello «enjendró [sic] en el Perú contra Bolivia odios inestinguibles [sic]». ${ }^{109}$

Esa batalla permitió a Ballivián la aprobación de una constitución calificada por Velasco, como hiciera Arguedas, de «ordenanza militar», ${ }^{110}$ y los laureles le permitieron impunidad para fluctuar «entre los partidos, pasando rápidamente de los unos a los otros para descontentar a todos, y enjendrar [sic] el odio jeneral [sic] a su inconsecuencia». Introdujo el caos en el gobierno por sus continuos cambios de bando, coartó la libertad electoral e injurió a toda voz discordante. Velasco ideó en su texto un paisaje apocalíptico: Ballivián degradó a los antiguos héroes de la independencia y relegó a los jueces a ser portavoces de sentencias que él fabricaba. El gabinete era caótico, y su gestión, arbitraria. Las familias de opositores, como Belzu, atacadas, así como abierta la correspondencia privada, mientras copiaba letras para hacer pasar por suyas algunas cartas. La educación pública estaba en un estado lamentable, desacreditada, habiendo desaprovechado la juventud de la generación. Leyes que justificaban sus acciones por doquier, habiendo derogado el corpus legislativo del mandato anterior; «una monstruosa deficiencia», amparada por la victoria en Ingavi, algo que ya no podía justificarlo. ${ }^{111}$

La «victoria de la soberanía de la razón, que Ballivián ha puesto en pugna y lucha escandalosa con el poder del sable, del puñal y del veneno», ${ }^{112}$

109 Idem.

110 «Vencedor en Ingavi a la cabeza del Ejército, única institución que reconoce si él lo manda, y aun no enjugadas las lágrimas de muchas familias, ni disipado el terror, Ballivián mandó que el Congreso sancionase una Constitución ya antes orgánicamente impresa en su alma Neroniana» (Ibidem, 11; Arguedas, 1967 [1922], 115).

111 «El vencedor de Ingavi con vanas pretensiones a la inmortalidad, no se crea cobijado por el jenio [ $\mathrm{sic}$ ] de la gloria, mientras su corazón metalizado palpite no más que para el interés personal» (Velasco, 1848, 13-15, 18).

112 Ibidem, 21. 
estaba en las manos de Velasco. Tirano de espaldas a la ley, para él Ballivián había ahogado la voluntad nacional en la suya propia, creando una oligarquía partidista que imperaba, oprimía, explotaba y humillaba al legislativo. Un traidor vendepatria que ataca a opositores sin más justificación que la venganza, soportado por los laureles de Ingavi. En definitiva, un monstruo a sacrificar por el porvenir de Bolivia. Ballivián debía ser el Gamarra de Velasco que lo legitimara en la responsabilidad asumida, ante el auge de otros pretendientes militares, como Belzu. Si las afirmaciones de Velasco eran o no verídicas no era tan importante como que pudieran serlo, articulando un discurso coherente que sostuviera una aceptación popular para ejercer el poder.

En tercer lugar, apareció un documento muy representativo del relato que la oposición a Ballivián construyó alrededor de su figura, y que debía ayudar a Velasco a legitimarse en el poder destruyendo los preceptos justificadores del ballivianismo que habían imperado desde 1841. El «Testamento del Presidente Ballivián», ${ }^{113}$ bañado en ironía, pretendió acabar con toda traza de autoridad de la facción anterior, escribiendo en primera persona referida a un Ballivián que comunicaba supuestamente sus últimas voluntades.

«Temeroso del juicio que por mis infinitos crímenes merezco, en el que se me pedirá estricta cuenta de los caudales que han desaparecido, víctimas que he sacrificado, y un millón más de cargos de que me he hecho responsable», da una serie de instrucciones a hacer con él en su muerte. A lo primero que se hace referencia es a la condición de monstruo en la que se viene insistiendo en el artículo presente. El alma de Ballivián debía transmigrar a un tigre, «pues que igual a este he sido en ferocidad y sed de sangre y venganza», mientras que sus entrañas «se las den a un cocodrilo para que las una a las suyas, por la absoluta semejanza que hay entre los dos». Su cuerpo debía acompañar una columna de piedra a su memoria «en cuya cúspide se colocará mi busto en figura de tigre con cabeza de hombre, teniendo en su garra derecha un cordero, y en la izquierda una paloma, ambos con el cuerpo destrozado». ${ }^{114}$

El monstruo acudió al mando omnímodo por vía del faccionalismo, la traición y el engaño, a través del «incomparable afán con que trabajaron mi familia, el Negrito cimiento, el Pájaro bobo, el Macho frontino y

113 El texto ha sido encontrado en la Colección privada de documentos de Doña Florencia Ballivián, a quien aprovecho para agradecer enormemente la oportunidad.

114 Testamento del Presidente Ballivián, 1847, 1. 
otras varias mujeres, quienes pudieron seducir algunos militares que, con la tropa, me proclamaron Jefe Supremo». Una vez en la cúspide, coartó libertades, holló garantías constitucionales «porque no he reconocido otra [constitución] que mi caprichosa voluntad», arruinó el comercio y azuzó el atraso en todos sus ramos, la inmoralidad y la ruina del país. ${ }^{115}$ Según el texto, sus mayores atrocidades, como la rebelión, la inconstitucionalidad y el asesinato, fueron en paralelo a «la chismografía, premiando con profusión las delaciones, por cuyo medio me he sostenido en la Presidencia, y he sembrado la desconfianza entre amigos y parientes para evitar que se comunicasen» ideas contrarias a su administración. ${ }^{116}$

La base de su mandato, Ingavi, es atacada en sus cimientos, como hiciere Velasco, mostrando cierta intertextualidad con las afirmaciones de este expuestas anteriormente. El texto afirma, en una supuesta primera persona, que Ballivián debía:

la vida al Jeneralísimo [sic] del Perú D. Agustín Gamarra, a quien habiéndolo llamado en mi auxilio con su Ejército para apropiarme la Presidencia de esta República, lo batí en Ingavi, por no haberme podido sobreponer a la voluntad de la Nación, a la que engañé haciéndolo aparecer como invasor, faltando a los compromisos que con él contraje y correspondiendo con ingratitud a los servicios de amistad que jenerosamente [sic] me prodigó en todo el tiempo de mi proscripción. ${ }^{117}$

Algo que parecía dilucidarse en Velasco en el Testamento es afirmado sin filtro, y es que Gamarra fue un simple instrumento inerte, un ente a las órdenes de un Ballivián que lo engañó, poniendo en peligro tanto a Bolivia como al Perú para su gloria personal en batalla. Ingavi fue culpa de Ballivián, y la usó para fundamentar su presidencia en la lealtad militar. Su sentimiento de romántica marcialidad se trasladó al gobierno, dilapidando el erario en el mantenimiento del ejército que, junto con la corrupción, serían los causantes de la ruina del país. ${ }^{118}$

Habiendo expuesto las principales fallas en el paso de Ballivián por la primera línea político-militar boliviana, traslada a sus doce albaceas, a modo de mandamientos de obligado cumplimiento en la conducta, sus voluntades:

115 Idem.

116 Idem.

117 Ibidem, 2.

118 «Declaro que debo al Estado cuatro millones de pesos que he defraudado, fuera de lo que con mi consentimiento han robado mis ajentes [sic]» (Idem). 
1. ${ }^{\mathrm{a}}$ Que es su voluntad asignar a la $1 .^{\mathrm{a}}$ albacea su desmedida codicia: al $2 .^{\circ}$ el absolutismo: al $3 .^{\circ}$ la arrogancia: al $4 .^{\circ}$ la astucia y perfidia: al $5 .^{\circ}$ la dilapidación e inmoralidad: al $6 .^{\circ}$ el asesinato: al $7 .^{\circ}$ la infidelidad conyugal: al $8 .^{\circ}$ la sed de sangre y ambición al mando Supremo: al 9..$^{\circ}$ la imbecilidad: al $10 .^{\circ}$ la bajeza e ineptitud: al $11 .^{\circ}$ la cobardía y suciedad, y al $12 .^{\circ}$ la presunción; ordenando y mandando que cada uno de los beneficiados se contente con lo asignado, por que es la parte que debe llevar en rigor de justicia; y que ninguno de ellos promueva pleito para apropiarse lo asignado al otro, por que deben hacerse una mutua cesión a fin de que todos toquen su parte. Así lo dispone para que lo cumplan y ejecuten con aquella ciega sumisión con que siempre han obedecido sus mandatos injustos y temerarios. ${ }^{119}$

Esos 12 mandamientos de la ignominia no fueron lo único que debía dejar en herencia; para sus hijos «lejítimos [sic], naturales y adulterinos les asigna en herencia los famosos renombres de parricida, asesino, ladrón, déspota, tirano y tigre feroz de Cebollullo». ${ }^{120}$ Ballivián había corrompido todo a su alrededor, y los sospechosos de afirmar su doctrina o seguir su facción tenían en ellos la etiqueta del monstruo que el presidente irradiaba.

Los tres textos muestran coincidencias claras en la crítica a José Ballivián. Pérfido, monstruo instalado en la excepcionalidad, sin miedo a traspasar las líneas de la legalidad por controlar el poder central. Con el legislativo acallado, la ciudadanía se sometió al vencedor de Ingavi por la gloria que supuso una victoria que confirmaba la segunda independencia. No obstante, al ser provocada por el propio tirano, la consideración de la batalla como momento glorioso se pone en duda (Guilarte) o se descarta (Velasco, Testamento), deslegitimando la base fundacional bélica para la administración de Ballivián y derrumbando la base histórico-discursiva de su autoridad.

Cortés consideró que «el vencedor de Ingavi, debió a la victoria sus títulos al mando de Bolivia; pero si la gloria puede fundar un gobierno, solo la libertad, el respeto a los derechos de la sociedad i la probidad política pueden sostenerlo». ${ }^{121}$ Otros, como Sotomayor Valdés, atinaron a decir que «Ballivián durante su gobierno consumió, por decirlo así, su patrimonio de Ingavi, que una vez concluido, lo dejó frente a frente de las aspiraciones de la nación por la libertad». ${ }^{122}$ Ingavi no podía, en sus palabras, justificar los atropellos cometidos por Ballivián a las libertades de Bolivia, y su legitimidad se acabó por sí misma. No se dice que, como se ha expuesto,

119 Idem.

120 Idem.

121 Cortés, $1861,188$.

122 Sotomayor Valdés, 1874, 84. 
su legitimación en el poder fue contrarrestada hasta acabar con ella por la construcción de un discurso opositor a la figura de Ballivián substitutivo del laudatorio.

\section{Reflexiones finales}

La batalla de Ingavi fue ensalzada como la segunda independencia de Bolivia. Momento fundacional, la unión del país en el clamor para derrotar al monstruo, el tirano en el que se convirtió el invasor Gamarra, permitió la victoria boliviana. La Bolivia rota en facciones desde la marcha de Sucre, pasados pocos años de su creación, fue unificada para conservar su independencia en la figura de José Ballivián. Este, presentándose como una tercera vía política, acabó por adquirir centralidad en el panorama político capitalizada con la victoria contra el Perú. La gloria y muerte del tirano justificó su tercera vía y la legitimó en el poder.

Para que tales consideraciones se trasladaran a la sociedad, se glorificó la batalla de Ingavi para constituirla como base histórico-discursiva de la administración de Ballivián. Ello resultó de inundar la opinión pública con el laudo a la victoria y a su héroe, único boliviano capaz de unir todas las facciones existentes, de acabar con la lucha partidista, para asegurar un brillante futuro económico y social para el país. El propio Ballivián participó directamente, publicando los partes de guerra, proclamas, decretos y folletos alrededor de la batalla y de sus soldados; ${ }^{123}$ la Iglesia ayudó en la deificación del suceso; ${ }^{124}$ intelectuales acentuaron la importancia de la victoria y la unión de partidos en el camino del progreso, ${ }^{125}$ la literatura mistificó el aura del héroe. ${ }^{126}$ El proceso en cuestión permitió un giro hacia la primacía del ejecutivo reblado en la constitución de 1843 gracias al supuesto fin de las facciones contrarias. La historiografía posterior, por su parte, se ocupó de consolidar la batalla como mito patriótico, base de la existencia de Bolivia, momento fundacional de la historia patria. ${ }^{127}$

La importancia de Ingavi caló profundamente en la sociedad boliviana, legitimando en el discurso el prolongado mandato de José Ballivián.

123 Ballivián, 1841.

124 Discurso pronunciado..., 1842.

125 Prudencio, 1842a; 1842b. Frías, 1844; 1846.

126 La jornada..., 1841. Bustamante, 1853.

127 Camacho, 1896. Arguedas, 1967 [1922]. 
Por tal razón, imperaba la construcción de un discurso alternativo que acabara con la preponderancia del dominante si se quería socavar la autoridad del presidente. (Re)inundar la opinión pública de un discurso discordante, creando en Ballivián un nuevo monstruo que tomara los rasgos del pérfido y personalista Gamarra. La llegada de nuevos liderazgos se vio legitimada por la supuesta tiranía y partidismo de Ballivián, que había provocado él mismo la batalla de Ingavi para su beneficio político, poniendo en peligro a la patria. ${ }^{128}$ Se trató de destruir Ingavi, acto marcial temerario e irracional, para acabar con Ballivián, personificación de todos los defectos atribuidos al «caudillo» decimonónico latinoamericano. ${ }^{129}$

Puede considerarse que, en parte, el poder presidencial de Ballivián, marginal con anterioridad, fue aceptado por la sociedad y no cuestionado durante un tiempo prolongado dada la importancia construida alrededor de su figura como unificador de partidos capaz de conseguir la segunda independencia. Derrotar a Gamarra, monstruo que encarnaba todo valor negativo adscrito a un gobernante, lo convirtió en pater patriae y otorgó confianza a su acción ejecutiva con la creación de un discurso laudatorio sobre el suceso de Ingavi, momento fundacional de Bolivia. A su caída, ese discurso fue substituido en la opinión pública por otro que preconizaba la responsabilidad de Ballivián en la existencia de la guerra contra el Perú. Si él había provocado la batalla, su victoria no tenía el mérito que se le otorgaba, y haber puesto en peligro la independencia lo convertía en un nuevo monstruo político, además de la tiranía partidista y corrupta que había seguido a la gloria del episodio bélico. Batirlo debía legitimar la creación de un nuevo liderazgo, como el de Guilarte o Velasco. La sucesión de acontecimientos crea un esquema en donde aparece el pretendiente en contradicción con un tirano (Ballivián-Gamarra/Velasco/Guilarte-Ballivián); el primero derrota al segundo, por medio de la batalla o la revolución (episodio bélico) y, habiendo salvado la patria, es legitimado por la ciudadanía para servir como líder del ejecutivo.

Fuera como fuere, aunque el esquema funcionó con Ballivián, tanto Guilarte como Velasco pasaron por la presidencia de forma fugaz ante el auge de Belzu, quien capitalizó la oposición al ballivianismo. ${ }^{130}$ Sucesivos auges y caídas pudieron tener características parecidas en el siglo XIX

128 Velasco, 1848.

129 Testamento..., 1847.

130 Shchelchkov, 2011, 98. 
boliviano (véase los casos de Belzu y Melgarejo, ${ }^{131}$ demonizados por la historiografía tradicional a su caída) o en el ámbito latinoamericano (célebre es la presidencia argentina de Juan Manuel de Rosas). En la época de construcción del liberalismo, de pugna entre diferentes proyectos nacionales, la estrategia discursiva de construcción-destrucción de legitimidades pudo ser un fenómeno transversal en el panorama político de la región como tinte específico de la vía latinoamericana al liberalismo, de lo que el presente artículo pretende ser un análisis de caso.

Recibido, 27 de septiembre de 2019 Segunda versión, 29 de mayo de 2020 Aceptado, 10 de junio de 2020

\section{Referencias bibliográficas}

Aranzaes, Nicanor, Las Revoluciones de Bolivia, La Paz, Talleres Gráficos La Prensa, 1918.

Arguedas, Alcides, Historia general de Bolivia: el proceso de nacionalidad, 1809 1921, La Paz, Puerta del Sol, 1967 [1. a ed. 1922].

Ballivián, José, A mis contemporáneos, Tacna, Imprenta de la Beneficencia, 1840a. Ballivián, José, A mis compatriotas, Tacna, Imprenta de la Beneficencia, 1840b.

Ballivián, José, Campaña de cuarenta días, hecha por el Ejército boliviano al mando de S. E. el Jeneral D. José Ballivián, contra el Ejército invasor del Perú a las órdenes del Jeneralísimo de sus armas D. Agustín Gamarra, Sucre, Imprenta del Colejio de Artes, 1841.

Bridikhina, Eugenia, «La propaganda política y creación del nuevo lenguaje festivo en los primeros años de la república de Bolivia: rupturas y continuidades», Espacio, Tiempo y Forma. Serie V, Historia Contemporánea, 22, Madrid, 2010, 235-255.

Bustamante, Ricardo José, A la gloriosa memoria del inmortal D. José Ballivián, Cochabamba, s/e, 1853.

Camacho, José María, Compendio de historia de Bolivia, La Paz, Tipografía Comercial, 1896.

Carrasco, Manuel, José Ballivián, 1805-1852. Estampas históricas, Buenos Aires, Hachette, 1960.

Chartier, Roger, El mundo como Representación. Historia Cultural: entre práctica y representación, Barcelona, Editorial Gedisa, 1992.

131 En el caso de Belzu, su imagen fue reformada en el siglo XX (Crespo, 1980. Shchelchkov, 2011). Melgarejo no tuvo el mismo destino, quedando, hasta hoy día, como uno de los peores presidentes de la historia boliviana en el imaginario colectivo (Valencia, 1990). 
Colàs, Pol, «Auge y caída de Andrés de Santa Cruz y su Confederación: el “imperio de la traición” y la legitimación caudillista», Boletín Americanista, 79, Barcelona, 2019a, 47-67.

Colàs, Pol, «Una aproximación historiográfica al "caudillo" Andrés de Santa Cruz», Naveg@mérica. Revista electrónica editada por la Asociación Española de Americanistas, 22, Murcia, 2019b, 1-31.

Colección Oficial de Leyes, Decretos, Órdenes y Resoluciones Supremas que se han expedido para el Régimen de la República Boliviana, Sucre, Imprenta de López, 1858.

Cortés, José Domingo, Galeria de Hombres célebres de Bolivia, Santiago, Imprenta de la República, 1869.

Cortés, Manuel José, Ensayo sobre la historia de Bolivia, Sucre, Imprenta de Beeche, 1861.

Crespo, Alfonso, Manuel Isidoro Belzu: historia de un caudillo, La Paz, Última Hora, 1980.

Démelas, Marie-Danielle, Nationalisme sans nation?: la Bolivie aux XIXe-XXe siècles, París, Centre national de la recherche scientifique, 1980.

Derrida, Jacques, Márgenes de la filosofía, Madrid, Ediciones Cátedra, 1998.

Discurso pronunciado por el Dr. José María Yáñez de Montenegro, cura propio de la doctrina de Chulumani, y Vicario Jeneral del Ejército, en el solemne aniversario del Glorioso Triunfo de Ingavi, el 10 de Noviembre, Sucre, Imprenta de Castillo, 1842.

Frías, Félix, El cristianismo católico considerado como elemento de civilización en las repúblicas hispano-americanas, Valparaíso, Imprenta del Mercurio, 1844.

Frías, Félix, Nota dirijida a S.G. el señor Don Tomás Frías, ministro de Relaciones Exteriores de Bolivia, por Don Félix Frías, cónsul de la misma República en Chile, Valparaíso, Imprenta del Mercurio, 1846.

García Jordán, Pilar, Cruz y arado, fusiles y discursos: la construcción de los Orientes en el Perú y Bolivia, 1820-1940, Lima, Instituto Francés de Estudios Andinos/Instituto de Estudios Peruanos, 2001.

García Jordán, Pilar y Sala i Vila, Núria (coords.), La nacionalización de la Amazonía, Barcelona, Publicacions Universitat de Barcelona, 1998.

Groff Greever, Janet, José Ballivián y el Oriente boliviano, La Paz, Empresa Editora Siglo, 1987.

Guilarte, Eusebio, El General Guilarte, Arequipa, Imp. de Francisco Ibáñez, 1848.

Guiteras Mombiola, Anna, De los llanos de Mojos a las cachuelas del Beni, 18421938, Cochabamba, Itinerarios Editorial, 2012.

Habermas, Jürgen, Between facts and norms, Cambridge, Polity Press, 1996.

Irurozqui, Marta, «El pueblo soberano versus la plebe proselitista. Discurso historiográfico y etnización política en Bolivia, 1825-1922», en Palacios, Guillermo, La nación y su historia: Independencias, relato historiográfico y debates 
sobre la nación. América Latina, siglo XIX, Ciudad de México, El Colegio de México, 2010, 231-284.

Irurozqui, Marta, «"A resistir la conquista". Ciudadanos armados en la disputa partidaria por la revolución en Bolivia, 1839-1842», Boletín del Instituto de Historia Argentina y Americana Dr. Emilio Ravignani, 42, Buenos Aires, 2015, 60-91.

Irurozqui, Marta, «Ciudadanía armada versus caudillismo. Tres historias bolivianas sobre violencia y ley constitucional, 1841-1875», en Tabanera, Núria y Bonaudo, Marta (coords.), América Latina de la independencia a la crisis del liberalismo, 1810-1930, vol. V, Madrid, Marcial Pons, 2016, 99-131.

Irurozqui, Marta, Ciudadanos armados de ley. A propósito de la violencia en Bolivia, 1839-1875, La Paz, Plural/Instituto Francés de Estudios Andinos, 2018.

La jornada de Viacha, La Paz, Imprenta del Colejio de Artes, 1841.

Lukács, György, Teoría de la novela: un ensayo histórico-filosófico sobre las formas de la gran literatura época, Buenos Aires, Ediciones Godot, 2010.

Macías Kraljevic, Carlos, El Mariscal José Ballivián, salvador de la independencia nacional, La Paz, Instituto Geográfico Militar, 1991.

Malamud, Carlos, «¿Cuán nueva es la nueva historia política latinoamericana?», en Palacios, Guillermo (ed.), Ensayos sobre la nueva historia política de América Latina, Ciudad de México, El Colegio de México, 2007, 19-30.

Morelli, Federica, «Entre Ancien et Nouveau Régime. L'histoire politique hispano-américaine du XIXè siècle», Annales. Historie, Sciences Sociales, 4, París, 2004, 759-781.

Palacios, José Agustín, Exploración de los ríos i lagos del Departamento del Beni y en especial el Madera, practicada de orden del Supremo Gobierno de Bolivia, La Paz, Imprenta Paceña, 1852.

Paredes, Manuel Rigoberto, El General Don Josè Ballivián antes de Ingavi, Oruro, Asociación Internacional Boliviana, 1909.

Prudencio, Julián, Reseña del estado ruinoso de Bolivia por un ciudadano, Sucre, Imprenta de la Libertad, 1842a.

Prudencio, Julián, Cuaderno segundo de la reseña del estado ruinoso de Bolivia por un ciudadano, Sucre, Imprenta de la Libertad, 1842b.

Refutación de la Época al Republicano de Arequipa sobre varias cuestiones de público interés entre el Perú y Bolivia, La Paz, Imprenta de la Época, 1845.

Moreno, Gabriel René, José Ballivián, La Paz, Camarlinghi, 1970.

Rosanvallon, Pierre, Por una historia conceptual de lo político, Ciudad de México, Fondo de Cultura Económica, 2003.

Safford, Frank, «The Problem of Political Order in Early Republican Spanish America», Journal of Latin American Studies, 24, Cambridge, 1992, 83-97.

Santiváñez, José María, Vida del General José Ballivián, Nueva York, Imprenta del Comercio, 1891. 
Shchelchkov, Andrey A., La utopía social conservadora en Bolivia: el gobierno de Manuel Isidoro Belzu (1848-1855), La Paz, Plural, 2011.

Sotomayor Valdés, Ramón, Estudio histórico de Bolivia bajo la administración del jeneral D. José María de Achá: con una introducción que contiene el compendio de la guerra de independencia i de los gobiernos de dicha república hasta 1861, Santiago de Chile, Imprenta Andrés Bello, 1874.

Testamento del Presidente Ballivián, La Paz, Imprenta Paceña, 1847.

Valencia, Alipio, Mariano Melgarejo: una tiranía surgida de la feudalidad boliviana, La Paz, Librería Editorial Juventud, 1990.

Velasco, José Miguel de, Exposición y Protesta que hace el Mayor Jeneral José Miguel de Velasco como Presidente Legal de Bolivia contra la autoridad usurpadora y el Gobierno Ilegítimo del Jeneral José Ballivián, Sucre, Imprenta de Beeche y cía., 1848.

Weatherford, M. Stephen, «Measuring Political Legitimacy», American Political Science Review, 86:1, Cambridge, 1992, 149-166. 